\title{
PERENNIAL GRASSES TRAITS AS FUNCTIONAL MARKERS OF GRAZING INTENSITY IN BASALTIC GRASSLANDS OF URUGUAY
}

\author{
Martín Jaurena $^{1 *}$, Felipe Lezama ${ }^{2}$, and Pablo Cruz $^{3}$
}

\begin{abstract}
Natural grasslands in the basaltic region of Uruguay are threatened by an increase in stocking rates and changes in land use. To assess the effect of grazing intensification, plant functional types are proposed as simple tools to aid the monitoring and management of vegetation. In the present study we evaluated the effect of stocking rate increase at community level taking into account plant traits of 23 dominant perennial grass species. In order to identify plant functional types, we determined the grazing response in an experiment with two wethers stocking rates $\left(0.78\right.$ and 1.56 livestock units ha $\left.^{-1}\right)$ quantifying species cover and traits values. Leaf dry matter content (LDMC) and specific leaf area (SLA) were the traits that best described the perennial grasses response to the stocking rate increase and therefore are suggested to be used as functional markers. Three functional types were identified. Low stocking rates were related to functional type A (tall, warm season species with low SLA and high LDMC and functional type B (tall, cool-season species, with intermediate levels of leaf traits). On the other hand, high stocking rate encouraged functional type C (prostrate, warm season species, with high SLA and low LDMC). The classification of a highly diverse community into three functional types and the selection of traits as functional markers candidates is an innovative approach to develop simple and general methods to diagnosis the state of basaltic grasslands in Uruguay and to advise on its management.
\end{abstract}

Key words: Natural grasslands, diagnosis, management, stocking rate.

$\mathrm{T}$ here is a growing interest to understand the impact of different management practices on the sustainability of grassland ecosystems in Uruguay. Although natural grasslands represent the largest biome in the country $(70 \%$ total area) and provide valuable economic and ecosystem services, they are critically threatened by changes in land use and overgrazing (Díaz et al., 2006). Management of grasslands with high floristic diversity and a wide range of productive systems should assemble environmental conservation and production concerns (Bullock et al., 2001). In this context, increasing the abundance of perennial grasses (Dorrough et al., 2004) and particularly highly palatable cool-season grasses threatened by overgrazing (McIntyre and Lavorel, 2001) are important strategies for ensuring sustainability.

Natural grasslands are the typical vegetation of the basaltic region of Uruguay that comprises one-quarter of the country's area. The carrying capacity of this area is the

\footnotetext{
${ }^{1}$ Instituto Nacional de Investigación Agropecuaria INIA, Estación Experimental del Norte, Ruta $5 \mathrm{~km}$ 386, Tacuarembó, Uruguay. *Corresponding author (mjaurena@tb.inia.org.uy).

${ }^{2}$ Universidad de la República, Facultad de Agronomía, Avenida Eugenio Garzón 780, Montevideo, Uruguay.

${ }^{3}$ Institut National de la Recherche Agronomique INRA UMR 1428

AGIR, BP 52627, 31326 Castanet-Tolosan, France.

Received : 1 March 2012.
}

Accepted : 15 September 2012 lowest in Uruguay (0.6 to 0.8 livestock units per hectare) and there are proposals to increase wool production using higher stocking rates. This vegetation is mainly composed of perennial grasses of warm-season growing cycle with both caespitose and prostrate habit, and to a lesser extent by perennial grasses of cool-season growing cycle that are mostly caespitose habit. However, the effects of grazing intensification have not yet been evaluated. Many studies have described changes in botanical composition of these grasslands related to different stocking rates, but their results are difficult to use because they cannot be extrapolated to other types of pasture or to different climatic or grazing conditions. Understanding the effects of grazing intensity on the dynamics of native grassland communities is important to link animal production with the conservation of the ecosystem services. Plant functional types can be used as simple tools to aid the management and monitoring of the vegetation. Based on this context, we suggest that leaf traits and plant height $(\mathrm{PH})$ could be used to explain highly diverse basaltic grassland response to stocking rate increase and to classify the species responses into functional types.

The effect of grazing on species composition and diversity of grasslands remains controversial, but there is a growing agreement that plant functional types can predict the processes of grassland ecosystems (Díaz et al., 2001; McIntyre and Lavorel, 2001). In this approach, 
functional classification of grassland species tries to find groups of species with combinations of traits that show common responses to grazing intensity (McIntyre and Lavorel, 2001; Sosinski and Pillar, 2004; Evju et al., 2009). A similar response to treatments of grazing, mulching and burning was shown in different grasslands although they were floristically different. In that case hemicryptophytes were the dominant life form in all of the treatments that had in common the partial removal of biomass (Kahmen and Poschlod, 2008). The challenge of predicting community responses to grazing management has promoted a search for key community parameters with emphasis on morphophysiological traits (Gitay and Noble, 1997; Díaz and Cabido, 1997; Lavorel et al., 1997; Westoby, 1998; McIntyre and Lavorel, 2001; Rodríguez et al., 2003). Traits such as PH, leaf area, leaf thickness (Quadros and Pillar, 2001; McIntyre and Lavorel, 2001), leaf tensile strength (LTS) (Boggiano, 1995) and leaf form (Altesor et al., 1999) have been linked consistently with grazing intensity. A combination of height and other related traits can give a better indication of the different responses to mowing and grazing (Klimesova et al., 2008). Cruz et al. (2010) working with native grasslands of southern Brazil, showed that after 15 years of differential continuos grazing intensities it was possible to describe a gradient of grazing pressure by means of SLA and LDMC. These leaf traits are functional markers of species strategies for resource use (Ryser and Urbas, 2000; Garnier et al., 2004; Al Haj Khaled et al., 2005; Li et al., 2005) and are a useful approach for linking vegetation changes with ecosystem function (McIntyre, 2008). The use of LDMC has been promoted as an indicator of resource use (Wilson et al., 1999; Li et al., 2005) because it is related with growth rate (Gross et al., 2007). Besides that, LDMC is easy to measure, less variable between replicates and show lower correlation with leaf thickness than SLA (Wilson et al., 1999).

The objective of this work was to assess the response of the plant community associated with the stocking rate increase in basaltic grasslands of Uruguay, testing the indicator value of plant traits and identifying plant functional types. To be more specific, we addressed the following questions: I) Do plant traits of perennial grasses explain the community changes related with the stocking rate increase in basaltic grasslands? We expect that the stocking rate increase may lead to changes in group of species frequencies related to the community response to grazing pressures. Therefore, common traits of this species could be used as indicators of the community changes. II) Which functional types are related to grazing intensities? We expect that the stocking rate increase changes the relative proportions of functional types. These changes are related to a decrease in tall, coolseason growing perennial grasses and an increase in warm-season perennial prostrate grasses.

\section{MATERIALS AND METHODS}

\section{Site description}

Research was conducted at Glencoe Experimental Unit $\left(32^{\circ} 01^{\prime} 57^{\prime \prime} \mathrm{S}, 5^{\circ} 13^{\prime} 52^{\prime \prime} \mathrm{W}\right)$ of Instituto Nacional de Investigaciones Agropecuarias (INIA) located in the basaltic region of Uruguay. This region is part of the "campos" biome that includes East Central Argentina, South of Brazil, and Uruguay (Soriano, 1991). These temperate grasslands are dominated by $\mathrm{C}_{4}$ perennial warm season grasses and $\mathrm{C}_{3}$ cool-season grasses (Berretta, 2001; Jaurena et al., 2011). The mean annual rainfall is 1300 $\mathrm{mm}$, evenly distributed throughout the year, with mean temperatures of $25^{\circ} \mathrm{C}$ in summer and $12^{\circ} \mathrm{C}$ in winter. The present study was focused in Black Eutric Litosol soils with $\mathrm{pH} 6.1$, organic $\mathrm{C} 2.9 \%$, and a loam texture, which averaged a DM production of $3800 \mathrm{~kg} \mathrm{ha}^{-1} \mathrm{yr}^{-1}$ over a 14yr period (Berretta et al., 2001).

\section{Species grazing response}

A portion of a database corresponding to surveys on black soils of a grazing experiment carried out by Jaurena et al. (2011) was used to determine the species grazing response. This experiment studied from September 2006 to November 2007 the effect of two contrasting stocking rates: 5.4 and 10.8 Merino wethers ha $^{-1}$ (0.78 and 1.56 livestock units $\mathrm{ha}^{-1}$ ) in red and black shallow basaltic soils, using two replicate paddocks of 0.55 ha alternately grazed (Jaurena et al., 2011). The herbage mass was similar between treatments at the beginning but with major differences at the end of the experimental period with 2150 and $1010 \mathrm{~kg} \mathrm{ha}^{-1}$ pregrazing (Jaurena et al., 2011), and with 1604 and $537 \mathrm{~kg} \mathrm{ha}^{-1}$ postgrazing for low and high stocking rate respectively. Of 83 taxa recorded in black soils, the 23 most abundant perennial grasses (seventeen warm-seasons and six cool-seasons) found with a minimum average cover of $0.4 \%$ were selected to assess its traits. The selection of species was based in the "biomass ratio hypothesis" proposed by Grime (1998). It postulates that ecosystem's properties are related to species contribution to the total biomass of the community (Garnier et al., 2004). This hypothesis implies that the ecosystems functions are determined to a large extent by the trait values of the dominant species. Based on this hypothesis, we evaluated only perennial grasses since they are the dominant group that explains 50 to $90 \%$ of forage biomass production at Rio de la Plata grasslands (Berretta, 2001; Cruz et al., 2010; Jaurena et al., 2011).

\section{Species trait measurements}

In order to separate the effect of species replacement from that of trait plasticity to grazing intensities, we measure plant traits at only one site in a field area without grazing. This area was close to the grazing experiment and had similar soil conditions and grazing history. To standardize 
plant growth conditions the standing biomass was cut at the beginning of spring 2008. After a period of 60-70 d of growth without grazing, at vegetative stage, biomass of the 23 most abundant perennial grasses was harvested. Following the recommendations of the protocols proposed by Cornelissen et al. (2003), five randomly selected (one per quadrant of $5 \mathrm{~m} \times 20 \mathrm{~m}$ ) adult individuals per species showing no pathogen or hervibory symptoms were collected. Five traits were measured: SLA, LDMC, LTS, PH and leaf width (LW). To calculate SLA (leaf area per unit of dry weight, $\mathrm{m}^{2} \mathrm{~kg}^{-1}$ ) 20 newly-expanded leaves from four different tillers of five individuals were scanned using a leaf area meter (CI-202 CID, Scanman, Logitech, Newark, California, USA). The same 20 leaves were used to calculate LDMC (leaves DM per unit fresh mass of water-saturated leaves, $\mathrm{g} \mathrm{kg}^{-1}$ ) (Garnier et al., 2001; Cornelissen et al., 2003), and LTS ( $\left.\mathrm{N} \mathrm{mm}^{-1} \mathrm{LW}\right)$ measured in the central section of the leaf using a portable "tearing apparatus" described by Hendry and Grime (1993). Vegetative PH was measured from the base to the tip of the highest green leaf on 10 individuals (ignoring the flag leaf and reproductive parts of the plants) following the protocols of Cornelissen et al. (2003). Leaf width was measured as maximum LW in the same 20 leaves used in the former traits.

\section{Data analysis}

The floristic database was used to elaborate a matrix of the species cover of the 23 species for the two contrasting treatments of grazing intensities. The stocking rate effects on plant cover were evaluated in an ANOVA. Species were grouped in whole perennial, warm or cool-season, and clonal grasses (with large rizomes or stolons) according to the classifications of Rosengurtt (1979). In this analysis the general linear models were adjusted considering the effect of stocking rates using a mixed model with SAS version 9.1.3 (SAS Institute, 2005). Mean scores of the significant effects were compared using the Tukey test $(\mathrm{p}<0.05)$. For each of the 23 selected species a grazing response index (GRI) proposed by Noy-Meir and Oron (2001) was calculated in the following way: GRI $=$ (HSR - LSR)/(HSR + LSR), where HSR is the mean species cover on high stocking rate paddocks and LSR is the mean species cover on low stocking rate paddocks. The GRI expresses the relative change in abundance of each species associated with the stocking rate increase (Table 1). At the species level, regression analysis between traits and GRI were made for warm-season grasses separately (n = 16) using the software InfoStat/P (InfoStat, 2008). The regressions were reanalyzed excluding Schizachyrium spicatum (Spreng.) Herter because its "decreaser" response (see below) to grazing intensity was mainly related to its weak anchorage that leads to tillers damaged by animals and was not linked with its traits values.

An analysis of trait responses to grazing intensity and then a functional group classification was made adapting the five-step method proposed by McIntyre and Lavorel (2001): 1) Species responses to stocking rates were examined with the INDVAL method proposed by Dufrene and Legendre (1997) using the software PC-ORD 5.0 (McCune and Mefford, 2006). Species with INDVAL values $>50$ and GRI values $>0.15$ were classified as increasers (higher cover at high stocking rate) or GRI less than $<-0.15$ were categorized as decreasers (higher cover at low stocking rate) and the rest were classified as neutral (low INDVAL or non significant). 2) Groups of species with similar trait values were identified using Principal Component Analyses (PCA). Data were standardized

Table 1. List of the 23 studied species, growing cycle, grazing response index (GRI) and species abbreviation. The GRI index varies between -1 (species present only on low stocking rate paddocks) and +1 (species present only on the high stocking rate paddocks).

\begin{tabular}{|c|c|c|c|c|c|}
\hline Species & $\begin{array}{l}\text { Growing } \\
\text { cycle }\end{array}$ & GRI & LSR & HSR & $\begin{array}{c}\text { Species } \\
\text { abbreviation }\end{array}$ \\
\hline Aristida echinulata Roseng. et Izag. & Warm season & -0.71 & 2.25 & 0.38 & Ar ec \\
\hline Aristida murina Cav. & Warm season & -0.40 & 1.31 & 0.56 & Ar mu \\
\hline Aristida uruguayensis Henrard & Warm season & -0.60 & 1.50 & 0.38 & Ar ur \\
\hline Aristida venustula Arechav. & Warm season & -0.56 & 4.38 & 1.25 & Ar ve \\
\hline Axonopus affinis Chase & Warm season & 0.96 & 0.02 & 0.77 & Ax af \\
\hline Bothriochloa imperatoides (Hack.) Herter & Warm season & -0.20 & 0.94 & 0.63 & Bo im \\
\hline Bothriochloa laguroides (DC.) Herter & Warm season & 0.01 & 4.75 & 4.88 & Bo la \\
\hline Bouteloua megapotamica (Spreng.) Kuntze & Warm season & -0.18 & 2.63 & 1.81 & Bo me \\
\hline Briza subaristata Lam. & Cool season & -0.38 & 1.81 & 0.81 & $\mathrm{Br} \mathrm{su}$ \\
\hline Chloris grandiflora Roseng. \& Izag. & Warm season & -0.24 & 1.44 & 0.88 & Ch gr \\
\hline Coelorachis selloana (Hack.) A. Camus & Warm season & 0.96 & 0.02 & 0.77 & Co se \\
\hline Eragrostis lugens Nees & Warm season & -0.20 & 0.94 & 0.63 & Er lu \\
\hline Eustachis bahiensis (Steud.) Herter & Warm season & 0.01 & 4.75 & 4.88 & Eu ba \\
\hline Melica rigida $\mathrm{Cav}$. & Cool season & -0.18 & 2.63 & 1.81 & Me ri \\
\hline Nassella neesiana (Trin. \& Rupr.) Barkworth & Cool season & -0.53 & 21.56 & 6.62 & Na ne \\
\hline Paspalum notatum Flüggé & Warm season & 0.16 & 8.88 & 12.31 & Pa no \\
\hline Paspalum plicatulum Michx. & Warm season & -0.33 & 1.38 & 0.69 & Pa pl \\
\hline Piptochaetium montevidense (Spreng.) Parodi & Cool season & -0.14 & 2.81 & 2.13 & Pi mo \\
\hline Piptochaetium stipoides (Trin. \& Rupr.) Hack. ex Arechav. & Cool season & -0.01 & 2.63 & 2.56 & Pi st \\
\hline Schizachyrium spicatum (Spreng.) Herter & Warm season & -0.74 & 2.50 & 0.38 & Sc sp \\
\hline Sporobolus indicus (L.) R. Br. & Warm season & 0.33 & 0.30 & 0.59 & $\mathrm{Sp}$ in \\
\hline Steinchisma hians (Elliott) Nash & Warm season & 0.71 & 1.50 & 8.81 & St hi \\
\hline Stipa spp. & Cool season & 0.12 & 0.69 & 0.88 & St sp \\
\hline
\end{tabular}

LSR and HSR are the mean cover of green biomass of species at the low stocking rate and high stocking rate, respectively. 
subtracting the mean from the individual score and then dividing the difference by the standard deviation. Group memberships were graphically identified in biplot ordinations assisted by a minimum expansion tree using the software InfoStat (InfoStat, 2008). 3) Community aggregated trait responses to stocking rates were identified by fitting a general linear model. For each paddock, community aggregated trait values were calculated using the trait value of each species weighted according to its relative abundance in the paddock. Uniformity of proportions of low, medium, and high trait attributes categories (Table 2) between stocking rates was tested with the $\chi^{2}$ statistic using the software InfoStat (InfoStat, 2008). 4) Species were classified based on its combination of trait attributes in low or high stocking rate (species that had all of five significant attributes related to each stocking rate, or with a subset of four out of five significant attributes related to the stocking rate and the other one neutral) or indeterminate in the cases of neutral or conflicting responses. 5) Functional types were established by sets of species of each PCA group that had congruence of its traits classification with its grazing response.

\section{RESULTS AND DISCUSSION}

\section{Species traits and grazing response}

The 23 selected perennial grasses represent $95 \%$ of the total biomass cover of all the grasses recorded and contributed 69 and $58 \%$ to the cover of green biomass in low and high stocking rate respectively. Grazing intensity changed the relationships between warm and cool-season grasses. The whole set of perennial grasses and specifically cool-season perennial grasses decreased as stocking rate increased $(\mathrm{p}<0.05)$, while clonal species were not affected by the increase of the stocking rate (Figure 1). The main changes related to grazing intensity were consistent with previous studies that reported the decrease of tall cool-season grasses with the increase in grazing intensity in North American mixed-grass prairies (Manley et al., 1997; Derner and Hart, 2007), in Uruguayan grasslands (Rodríguez et al., 2003; Altesor et al., 2005) and a decrease in all perennial grasses in Australia (Lavorel et al., 1997; McIntyre and Lavorel, 2001). The tall grasses are better adapted to capture resources at low grazing intensities, but are less grazing resistant under high grazing intensities (Cingolani et al., 2005). This can be explained because tall cool-season grasses have less leaf area index after grazing, less reserve organs and their growing points are more exposed to damage comparing with prostrate grasses.

The single trait most associated with the stocking rate response of the 23 species was the LDMC, achieving $40 \%$ of the variability of the GRI that can be attributed to a linear relationship with that trait (Figure $2 \mathrm{a}$ ). The exclusion of Schizachyrium spicatum from the warm-season grasses analysis improved the relationship between traits and the GRI, underlining the positive relationship between SLA and GRI, with $54 \%$ of the variability of the GRI that can be attributed to a linear relationship with SLA (Figure 2b).

The traits values weighted by the relative abundance of grasses varied significantly with the stocking rates (Table 2). The increase of the stocking rate augments SLA and LW, and decreased PH, LTS, and LDMC. In a similar

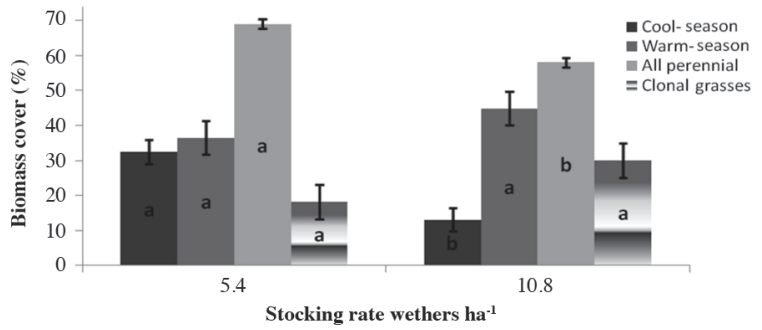

Figure 1. Results of the stocking rate effects on the cover of green biomass of all perennial grasses and perennial grasses classified by their season of growth (warm and cool season) and clonal strategy. Different letters between stocking rates correspond to significant differences $p<0.05$ and error bars represent standard errors.
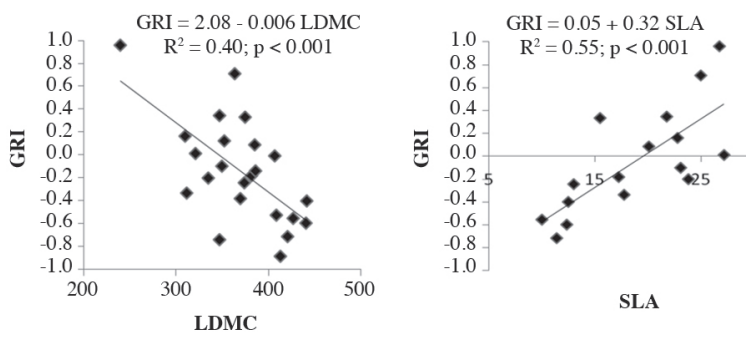

Figure 2a (left): Relationships for the 23 species of leaf dry matter content (LDMC) with grazing response index (GRI). Figure 2b (right): Relations in warm-season grasses excluding Schizachyrium spicatum of SLA with GRI $(\mathbf{p}<0.001)$.

Table 2. Low, medium, high and range values of trait attributes: Specific leaf area (SLA), leaf dry matter content (LDMC), leaf tensile strength (LTS), plant height $(\mathbf{P H})$, leaf width (LW), test of homogeneity of proportions of trait categories (low, medium and high attributes) using the $\chi^{2}$ Pearson statistic and result of analysis of variance of the stocking rate effects on trait variation (weighting species trait values by their relative abundance).

\begin{tabular}{|c|c|c|c|c|c|c|c|c|}
\hline & \multicolumn{4}{|c|}{ Attributes } & \multicolumn{4}{|c|}{ Traits ANOVA } \\
\hline & Low & Medium & High & Range & $\chi^{2}$ & LSR & HSR & $\mathrm{p}$ \\
\hline SLA, $\mathrm{m}^{2} \mathrm{~kg}^{-1}$ & $<15$ & $15-20$ & $>20$ & $10.0-27.1$ & $17.4^{* *}$ & 18.9 & 21.2 & 0.0002 \\
\hline $\mathrm{LDMC} \mathrm{mg} \mathrm{g}^{-1}$ & $<350$ & $350-400$ & $>400$ & $239-442$ & $12.8^{* *}$ & 377 & 351 & 0.0003 \\
\hline LTS, $\mathrm{N} \mathrm{mm^{-1 }}$ & $<2$ & $2-3.5$ & $>3.5$ & $0.9-6.8$ & $19.3^{* *}$ & 2.4 & 1.9 & 0.0002 \\
\hline $\mathrm{PH}, \mathrm{cm}$ & $<4$ & $4-7$ & $>7$ & $1.1-9.3$ & $9.4^{* *}$ & 5.9 & 5 & 0.0002 \\
\hline $\mathrm{LW}, \mathrm{mm}$ & $<2$ & $2-3.5$ & $>3.5$ & $0.7-5.5$ & $22.7 * *$ & 3 & 3.7 & 0.0017 \\
\hline
\end{tabular}


way, most classes of traits attributes (with the exception of medium levels of LDMC) also varied significantly with the stocking rate as was detailed before. High stocking rate was related to high proportions of short to mediumheight plants, with high SLA, low LDMC, wide and tender leaves. Low stocking rates were associated with higher proportion of tall plants, low to medium SLA, high LDMC, tough and narrow leaves. Leaf dry mater content and SLA were the leaf traits that best described the perennial grasses responses to the stocking rate increase and could be used as functional markers of grazing intensity to rank and monitoring basaltic communities at farm level. As functional markers this species traits could operate linking the grassland management to their consequences on ecosystem properties as proposed by Quetier et al. (2007). On short term this functional markers could be useful to adjust the grassland management and at medium to long term could be useful to know successional changes. As grazing pressure increases, there was a greater dominance of warm season, prostrate, wide-leaved perennial grasses, with low LDMC and high SLA. These patterns of response represent a functional trade-off linked with the species strategies of resource-use and plant growth in different environments (Díaz and Cabido, 1997; Weiher et al., 1999). A conservative strategy was associated with low stocking rate, characterized by the increase in species with a low SLA, in agreement with reports of Cingolani et al. (2005) and Leoni et al. (2009), and high LDMC. Our results were consistent with findings of Cruz et al. (2010) that reported LDMC and SLA as the traits that best described the response associated with the stocking rate increase. These results are also in agreement with the few papers describing functional studies of grazing intensity response in grassland communities of South America dominated by $\mathrm{C}_{4}$ warm season plants (Leoni et al., 2009;
Cruz et al., 2010). Leaf dry matter content emerges as an easily recorded functional marker that could explain the grazing impact at the agro ecosystem level but it should be validated on other spatial-temporal scales, since several trait responses are only significant when are examined on one vegetation type as detailed by Peco et al. (2005) and Kahmen and Poschlod (2008).

\section{Functional types}

The analysis of grazing response classified 12 species that were more abundant at low stocking rate as decreasers (low tolerance to intense defoliation); five species that were more abundant at high stocking rates as increasers (high tolerance to intense defoliation), and six species were grouped as neutral. Nine decreaser species were warm-season and three were cool-season, while the five increasers were all warm-season grasses (Table 3). Decreaser species have two different response strategies to stocking rate increase. The increase of functional type A of tall, warm season, species of Aristida at low stocking rate was explained by their low palatability. Meanwhile functional type B of more palatable tall, cool-season species had higher biomass at low stocking rates. The lack of response to the stocking rate of group of clonal species like Axonopus affinis Chase and Paspalum notatum Flüggé was unexpected, since in grasslands of Uruguay with a long history of continuous grazing Altesor et al. (1999) showed that vegetative propagation is the main form of reproduction. This response could be related to the increase in Steinchisma hians (Elliott) Nash at high stocking rate that masked the increase of clonal species. Steinchisma hians lack of clonal propagation but has a plastic growth habit, for which contradictory results about grazing response have been reported. Rosengurtt (1979) and Jaurena et al. (2011)

Table 3. Summary of results of principal component analysis (PCA) of trait variation and species grazing response (INDVAL-GRI) analysis to examine congruency in the 23 species.

\begin{tabular}{|c|c|c|c|}
\hline Species & PCA Group & Attribute summary & Stocking rate response \\
\hline Aristida echinulata & Narrow and tough leaves & Low stocking rate & Decreaser \\
\hline Aristida murina & Narrow and tough leaves & Low stocking rate & Decreaser \\
\hline Aristida uruguayensis & Narrow and tough leaves & Low stocking rate & Decreaser \\
\hline Aristida venustula & Narrow and tough leaves & Low stocking rate & Decreaser \\
\hline Briza subaristata & Quite tough leaves & Low stocking rate & Decreaser \\
\hline Melica rigida & Quite tough leaves & Inconsistent & Decreaser \\
\hline Nassella neesiana & Quite tough leaves & Low stocking rate & Decreaser \\
\hline Bouteloua megapotamica & Quite tough leaves & Inconsistent & Decreaser \\
\hline Chloris grandiflora & Quite tough leaves & Inconsistent & Decreaser \\
\hline Schizachyrium spicatum & Wide and tender leaves & High stocking rate & Decreaser \\
\hline Axonopus affinis & Wide and tender leaves & High stocking rate & Increaser \\
\hline Coelorachis selloana & Wide and tender leaves & High stocking rate & Increaser \\
\hline Steinchisma hians & Wide and tender leaves & High stocking rate & Increaser \\
\hline Paspalum notatum & Wide and tender leaves & High stocking rate & Increaser \\
\hline Piptochaetium montevidense & Quite tough leaves & Inconsistent & Neutral \\
\hline Piptochaetium stipoides & Quite tough leaves & Low stocking rate & Neutral \\
\hline Eragrostis lugens & Quite tough leaves & Inconsistent & Neutral \\
\hline Sporobolus indicus & Quite tough leaves & Inconsistent & Neutral \\
\hline Stipa spp. & Quite tough leaves & Low stocking rate & Neutral \\
\hline Bothriochloa imperatoides & Wide and tender leaves & Inconsistent & Neutral \\
\hline Bothriochloa laguroides & Wide and tender leaves & High stocking rate & Neutral \\
\hline Eustachis bahiensis & Wide and tender leaves & High stocking rate & Neutral \\
\hline Paspalum plicatulum & Wide and tender leaves & Inconsistent & Neutral \\
\hline
\end{tabular}


defined it as high stoking rate resistant; while León and Burkart (1998) and Altesor et al. (2005) reported that it frequency had increased in the early years of grazing exclusions.

The finding of more decreaser than increaser species agrees with the simple explanation given by Vesk et al. (2004) that to be a decreaser there are many combinations of traits, whereas a strict combination of them (high SLA and LW, and low PH, LTS and LDMC) is necessary to be an increaser. Most of species showed grazing responses consistent with previous reports (Rodríguez et al., 2003; Leoni et al., 2009), except Coelorachis selloana (Hack.) A. Camus and S. hians that did not showed a response consistent with previous results. Vesk and Westoby (2001) identified opposite grazing responses in a quarter of the species, attributing this to the different environmental contexts rather than specific traits. Other possible reasons for this conflicting response are the ecotypes variability, intraspecific trait variability, and phenotypic plasticity.

Three groups of species, defined by correlated traits, were identified in the PCA biplot (Figure 3). One group (wide and tender leaves) was characterized by short height, high levels of SLA and LW, and low levels of LDMC and LTS. Intermediate to high levels of LTS, LDMC and PH, and low to medium SLA and LW described the second group (quite tough leaves). High levels of LDMC and LTS, low levels of SLA and LW, and medium to high PH categorized the last group (narrow and tough leaves). The first one included nine warm season species characterized by short to medium $\mathrm{PH}$ with wide and tender leaves. The second group was formed by six cool-season species and four warm- season species with intermediate trait values. The third group was composed of four warmseason species of Aristida with hard and thin leaves. The group of wide and tender leaves were categorized by their attributes as high stocking rate species, while the quite tough leaves group was mainly classified as low stocking rate species. The narrow and tough leaves group presented only species with low stocking rate attributes.

One taxon (S. spicatum) had an inconsistent grazing response in relation to its trait values probably related to its weak tiller anchorage. All trait attributes that describe both stocking rates were used to define functional types which are related to the contrasting grazing intensities. Three species: A. affinis, C. selloana, and P. notatum, matched all the attributes for an increase functional type; meanwhile Aristida echinulata Roseng. \& Izag. had all the attributes for a decreaser functional type species. Other species were identified in functional types by a subset of traits. Two functional types were associated with low stocking rate, one group (Functional Type A) consisted of four warm season species of Aristida genus and the other (Functional Type B) was made up of two cool-season species: Nassella neesiana (Trin. \& Rupr.) Barkworth and Briza subaristata Lam. A third functional group (Functional Type C) included warm season species: the three species that matched all the attributes for high stocking rate and S. hians (Table 4). The observed pattern of changes in the relative abundance of functional types with stocking rates can be explained as a response of the

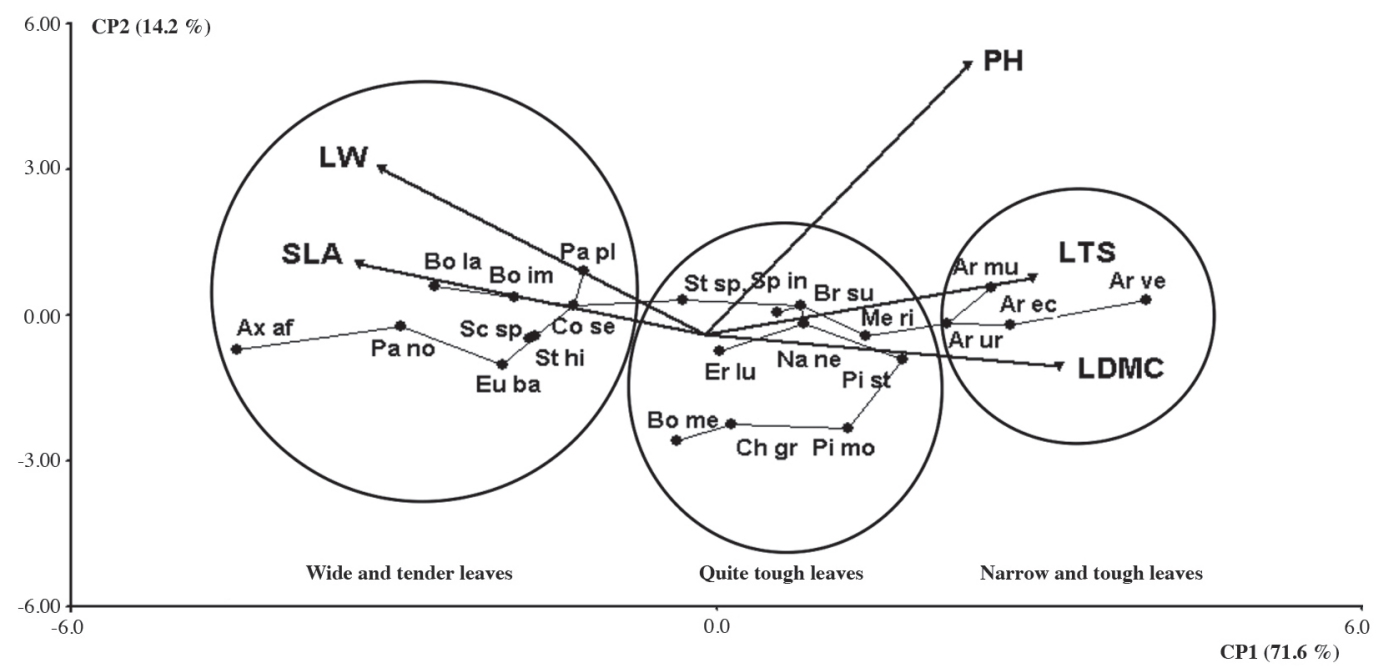

SLA: specific leaf area; LDMC: leaf dry matter content; LW: leaf width; PH: plant height; LTS: leaf tensile strength.

Ar ec: Aristida echinulata; Ar mu: A. murina; Ar ur: A. uruguayensis; Ar ve: A. venustula; Ax af: Axonopus affinis; Bo im: Bothriochloa imperatoides; Bo la: B. laguroides; Bo me: Bouteloua megapotamica; Br su: Briza subaristata; Ch gr: Chloris grandiflora; Co se: Coelorachis selloana; Er lu: Eragrostis lugens; Eu ba: Eustachis bahiensis; Me ri: Melica rigida; St hi: Steinchisma hians; Pa no: Paspalum notatum; Pa pl: P. plicatulum; Pi mo: Piptochaetium montevidense; Pi st: P. stipoides; Sc sp: Schizachyrium spicatum; Sp in: Sporobolus indicus; St sp: Stipa sp.; Na ne: Nassella neesiana.

Figure 3. Biplot of Principal Components Analysis of species traits. Groups are defined by correlated traits helped by a minimum expansion tree. Arrows represents the direction of the trait main effect and each point summarizes each species (denoted by the two first genus and species letters) position in the multivariate space. 
Table 4. Functional types: attributes associated with stocking rates and species groups agreement with the grazing response criterion.

\begin{tabular}{|c|c|c|c|c|c|}
\hline \multirow[b]{2}{*}{$\begin{array}{l}\text { Functional } \\
\text { type }\end{array}$} & \multicolumn{2}{|c|}{ Low stocking rate } & \multirow[b]{2}{*}{$\begin{array}{l}\text { Functional } \\
\text { type }\end{array}$} & \multicolumn{2}{|c|}{ High stocking rate } \\
\hline & Attributes & $\begin{array}{c}\text { Species } \\
\text { matching criteria }\end{array}$ & & Attributes & $\begin{array}{l}\text { Species } \\
\text { matching criteria }\end{array}$ \\
\hline A & $\begin{array}{l}\text { Tall plants, with narrow leaves, low } \\
\text { SLA, high LDMC and tough leaves. }\end{array}$ & $\begin{array}{l}\text { Aristida echinulata } \\
\text { Aristida murina } \\
\text { Aristida uruguayensis } \\
\text { Aristida venustula }\end{array}$ & $\mathrm{C}$ & $\begin{array}{l}\text { Short to medium tall plants with } \\
\text { wide leaves, high SLA and low } \\
\text { LDMC and tender leaves. }\end{array}$ & $\begin{array}{l}\text { Axonopus affinis } \\
\text { Coelorachis selloana } \\
\text { Paspalum notatum } \\
\text { Steinchisma hians }\end{array}$ \\
\hline B & $\begin{array}{l}\text { Tall plants, with intermediate width, } \\
\text { medium SLA, and quite tough } \\
\text { leaves. }\end{array}$ & $\begin{array}{l}\text { Briza subaristata } \\
\text { Nassella neesiana }\end{array}$ & & & \\
\hline
\end{tabular}

SLA: Specific leaf area; LDMC: leaf dry matter content.

community to the grazing environment, through changes in the frequency of abundant species and functional types. The pattern of grazing intensity specialization combines strategies of avoidance through short height and low palatability as described by Coughenour (1985) and tolerance by enhanced regrowth capacity (Briske, 1991). Good grassland management should focus on favouring a balanced contribution of acquisitive prostrate, warm season functional type $\mathrm{C}$ with the tall species functional types A and B. In this context, the management of basaltic grassland would have to use low stocking rates to maintain balanced grassland functions of livestock productivity and ecosystem resistance and resilience.

Relating the biomass ratio hypothesis (Grime, 1998) was a first step towards the simplification of traditional taxonomic analysis of high-diversity grasslands. Then, the classification of these species in functional groups assisted by key traits allowed to a higher level of simplification. This classification is a new tool to categorize species and communities that would complement the vegetative types proposed by Rosengurtt (1979), which is the most widely accepted guide in the management of natural grasslands in Uruguay. These findings are the base for developing a typology of basaltic grasslands as a way of simplifying the management and monitoring of these highly diverse basaltic grasslands communities. These grasslands are facing contradictory pressures in developing countries (Carvalho, 2006). There are demands to improve livestock production and there is a concern of resources sustainability. This problem leads to the need to synchronize efforts between production and conservation policies in the "campos" biome. In our experiment, stocking rate increase leads, at the community level, a decrease of functional type A of warm-season stress-tolerant species and a decline of functional type B of tall cool-season, which is balanced by an augment of functional type $\mathrm{C}$ of warm-season more grazing tolerant and fast growing but less stress-tolerant. The effects of the increase on grazing intensity are expected to further enlarge the inherent rainfall-related variability of forage production between seasons and years (Knapp et al., 2006), turning the decision-making process of stocking rate adjustment even more difficult and with negative impacts on livestock production.

\section{CONCLUSIONS}

Management of contrasting stocking rates in basaltic grasslands promoted plant functional types with certain common attributes. The present study enabled the classification of a highly diverse community into three functional types composed of perennial grasses with different strategies of response to the grazing intensities. The identification of leaf dry matter content and specific leaf area as key plant traits selected for functional markers of grazing intensity, is another important finding to understand the effects of stocking rate management on Uruguayan basaltic grasslands. Following this study, further research is needed to validate the usage of leaf traits and functional types as functional markers to predict the grazing intensity changes in other spatial-temporal scales in grasslands of Uruguay.

\section{ACKNOWLEDGEMENTS}

The work was supported by the Instituto Nacional de Investigación Agropecuaria (INIA), Uruguay. The authors gratefully acknowledged the forage staff of INIA Tacuarembó for their assistance with laboratory and field work. We also want to thank Janet Perrone, Gonzalo Martínez, Mercedes Rivas, Walter Ayala, Fernando de Quadros, Diego Michelini, María Bemhaja, and Claudia Marchesi for their helpful comments in the preparation of this article.

Rasgos de gramíneas perennes como marcadores funcionales de la intensidad de pastoreo en pastizales de basalto en Uruguay. Las praderas naturales de la región basáltica de Uruguay están amenazadas por el incremento de la carga animal y cambios en el uso del suelo. Para evaluar el efecto del pastoreo se han propuesto los grupos funcionales como una herramienta simple para el monitoreo y manejo de la vegetación. El presente estudio evaluó el efecto del incremento de la carga animal considerando rasgos de 23 especies de gramíneas perennes dominantes. Para identificar los grupos funcionales se determinó la respuesta al incremento de la intensidad de pastoreo en un experimento con dos cargas de capones $\left(0,78\right.$ and 1,56 unidades ganaderas ha $\left.{ }^{-1}\right)$ cuantificando la 
cobertura de dichas especies y los valores de sus rasgos. El contenido de MS y el área foliar específica fueron los rasgos que mejor describieron la respuesta de las gramíneas perennes al incremento de la carga animal y podrían ser utilizados como marcadores funcionales. Tres grupos funcionales fueron identificados. El nivel más bajo de carga animal se relacionó con el grupo funcional A (especies estivales, altas, con baja área foliar específica y alto contenido de MS) y con el grupo funcional B (especies invernales altas y con niveles intermedios de rasgos foliares). Por otro lado, el nivel más elevado de carga animal se relacionó con el aumento del grupo funcional C (especies estivales, postradas, con alta área foliar específica y bajos contenidos de MS). Esta clasificación de una comunidad con alta diversidad de especies en tres grupos funcionales es un nuevo enfoque para desarrollar métodos simples y generales para el diagnóstico del estado de praderas naturales de la región basáltica en Uruguay y generar recomendaciones para su manejo.

Palabras clave: praderas naturales, diagnóstico, manejo, carga animal.

\section{LITERATURE CITED}

Al Haj Khaled, R., M. Duru, J.P. Theau, S. Plantureux, and P. Cruz. 2005. Variation of leaf traits through seasons and nitrogen availability levels and its consequences for ranking grassland species. Journal of Vegetation Science 16:391-398.

Altesor, A., M. Oesterheld, E. Leoni , F. Lezama, and C . Rodríguez. 2005. Effect of grazing exclosure on community structure and productivity of a Uruguayan grassland. Plant Ecology 179:83-91.

Altesor, A., F. Pezzani, S. Grun, and C. Rodríguez. 1999 Relationship between spatial strategies and morphological traits in a Uruguayan grassland: A functional approach. Journal of Vegetation Science 10:457-462.

Berretta, E. 2001. Ecophysiology and management response of the subtropical grasslands of Southern South America. p. 939-946. In $19^{\text {th }}$ International Grassland Congress Sao Pedro, Sao Paulo. 1121 February 2001. Brazilian Society of Animal Husbandry, Sao Paulo, Brazil.

Berretta, E., D. Risso, y M. Bemhaja. 2001. Tecnologías para la mejora de la producción de forraje en suelos de basalto. INIABoletín de Divulgación 76. p. 1-37.

Boggiano, P.R. 1995. Relações entre estrutura da vegetação e pastejo seletivo de bovinos em campo natural. Dissertação Mestrado. Universidade Federal do Rio Grande do Sul (UFRGS), Porto Alegre, Brasil.

Briske, D. 1991. Developmental morphology and physiology of grasses. p. 85-108. In Heitschmidt, R., and J. Stuth (eds.) Grazing management: An ecological perspective. Timber Press, Portland, Oregon, USA.

Bullock, J.M., J. Franklin, M.J. Stevenson, S.J. Coulson, S.J. Gregory, and R. Tofts. 2001. A plant trait analysis of responses to grazing in a long-term experiment. Journal of Applied Ecology 38:253-267.

Carvalho, P.C.F. 2006. Access to land, livestock production and ecosystem conservation in the Brazilian Campos Biome: the natural grasslands dilemma. 10 p. In International Conference on Agrarian Reform and Rural Development (ICARRD), Porto Alegre, Brazil. 7-10 March. FAO, Rome, Italy.

Cingolani, A.M., G. Posse, and M. Collantes. 2005. Plant functional traits, herbivore selectivity and response to sheep grazing in Tierra del Fuego steppes, Argentina. Journal of Applied Ecology 42:50-59.
Cornelissen, J.H.C., S. Lavorel, E. Garnier, S. Díaz, N. Buchmann, D.E. Gurvich, et al. 2003. A handbook of protocols for standardised and easy measurement of plant functional traits worldwide. Australian Journal of Botany 51:335-380.

Coughenour, M.B. 1985. Graminoid responses to grazing by large herbivores: Adaptations, exaptations, and interacting processes. Annals of the Missouri Botanical Garden 72:852-853.

Cruz, P., F.L.F. Quadros, J.P. Theau, A. Frizzo, C. Jouany, M. Duru, and P.C.F. Carvalho. 2010. Leaf traits as functional descriptors of the intensity of continuous grazing in native grasslands in the south of Brazil. Rangeland Ecology and Management 63:350358 .

Derner, J.D., and R.H. Hart. 2007. Grazing-induced modifications to peak standing crop in northern mixed-grass prairie. Rangeland Ecology and Management 60:270-276.

Díaz, S., and M. Cabido. 1997. Plant functional types and ecosystem function in relation to global change. Journal of Vegetation Science 8:463-474.

Díaz, S., I. Noy-Meir, and M. Cabido. 2001. Can grazing response of herbaceous plants be predicted from simple vegetative traits? Journal of Applied Ecology 38:497-508.

Díaz, R., M. Jaurena, y W. Ayala. 2006. Impacto de la intensificación productiva sobre el campo natural en Uruguay. p. 49-67. In XXI Reunião do Grupo Técnico em Forrageiras do Cone Sul-Grupo Campos. 24-26 de outubro. Palestras e resumos. Embrapa Clima Temperado, Pelotas, Rio Grande do Sul, Brasil.

Dorrough, J., A. Yen, V. Turner, S.G. Clark, J. Crosthwaite, and J.R . Hirth. 2004. Livestock grazing management and biodiversity conservation in Australian temperate grassy landscapes. Australian Journal of Agricultural Research 55:279-295.

Dufrene, M., and P. Legendre. 1997. Species assemblages and indicator species: the need for a flexible asymmetrical approach. Ecological Monographs 67:345-366.

Evju, M., G. Austrheim, R. Halvorsen, and A. Mysterud. 2009 Grazing responses in herbs in relation to herbivore selectivity and plant traits in an alpine ecosystem. Oecologia 161:77-85.

Garnier, E., J. Cortez, G. Billés, M.L. Navas, C. Roumet, M. Debussche, et al. 2004. Plant functional markers capture ecosystem properties during secondary succession. Ecology 85:2630-2637.

Garnier, E., B. Shipley, C. Roumet, and G. Laurent. 2001. A standardized protocol for the determination of specific leaf area and leaf dry matter content. Functional Ecology 15:688-695.

Gitay, H., and I.R. Noble. 1997. What are plant functional types and how should we seek them? p. 3-19. In Smith, T.M., H.H. Shugart, and F.I. Woodward (eds.) Plant functional types. Cambridge University Press, Cambridge, UK.

Grime, J.P. 1998. Benefits of plant diversity to ecosystems: immediate, filter and founder effects. Journal of Ecology 86:902910 .

Gross, N., K. Suding, and S. Lavorel. 2007. Leaf dry matter content and lateral spread predict response to land-use change for six subalpine grassland species. Journal of Vegetation Science 18:289-300.

Hendry, G.A.F., and J.P. Grime. 1993. Methods in comparative plant ecology. Chapman and Hall, London, UK.

InfoStat. 2008. Manual del usuario. Grupo InfoStat, Facultad de Ciencias Agropecuarias, Universidad Nacional de Córdoba, Córdoba, Argentina.

Jaurena, M., O. Bentancur, W. Ayala, y M. Rivas. 2011. Especies indicadoras y estructura de praderas naturales de basalto con cargas contrastantes de ovinos. Agrociencia-Uruguay 15:103114 .

Kahmen, S., and P. Poschlod. 2008. Effects of grassland management on plant functional trait composition. Agriculture Ecosystems and Environment 128:137-145.

Klimesova, J., V. Latzel, F. de Bello, and J.M. van Groenendael. 2008. Plant functional traits in studies of vegetation changes in response to grazing and mowing: towards a use of more specific traits. Preslia 80:245-253. 
Knapp, A.K., C.E. Burns, R.W.S. Fynn, K.P. Kirkman, C.D. Morris, and M.D. Smith, 2006. Convergence and contingency in production-precipitation relationships in North American and South African $\mathrm{C}_{4}$ grasslands. Oecologia 149:456-464.

Lavorel, S., S. McIntyre, J. Lansberg, and T.D.A. Forbes. 1997. Plant functional classifications: from general groups to specific groups based on response to disturbance. Trends in Ecology and Evolution 12:474-478.

León, R., y S. Burkart. 1998. El pastizal de la pampa deprimida: estados alternativos. Ecotrópicos 11:121-130.

Leoni, E., A. Altesor, and J.M. Paruelo. 2009. Explaining patterns of primary production from individual level traits. Journal of Vegetation Science 20:612-619.

Li, Y., D.A. Johnson, Y. Su, J. Cui, and T. Zhang. 2005. Specific leaf area and leaf dry matter contents of plants growing in sand dunes. Botanical Bulletin of Academia Sinica 46:127-134.

Manley, W.A., R.H. Hart, M.J. Samuel, M.A. Smith, J.W. Waggoner, and J.T. Manley. 1997. Vegetation, cattle, and economic responses to grazing strategies and pressures. Journal of Range Management 50:638-646.

McCune, B., and M. Mefford. 2006. PC-ORD 5.0. Multivariate analysis of ecological data. Gleneden Beach, Oregon, USA.

McIntyre, S. 2008. The role of plant leaf attributes in linking land use to ecosystem function in temperate grassy vegetation. Agriculture, Ecosystems and Environment 128(4):251-258.

McIntyre, S., and S. Lavorel. 2001. Livestock grazing in subtropical pastures: steps in the analysis of attribute response and plant functional types. Journal of Ecology 89:209-226.

Noy-Meir, I., and T. Oron. 2001. Effects of grazing on geophytes in Mediterranean vegetation. Journal of Vegetation Science 12:749760.

Peco, B., I. de Pablos, J. Traba, and C. Levassor. 2005. The effect of grazing abandonment on species composition and functional traits: the case of dehesa grasslands. Basic and Applied Ecology 6:161-173.

Quadros, F.L.F., and V. Pillar. 2001. Dinâmica vegetacional em pastagem natural submetida a tratamentos de queima e pastejo. Ciência Rural 31:863-868
Quetier, F., A. Thebault, and S. Lavorel. 2007. Plant traits in a state and transition framework as markers of ecosystem response to land use change. Ecological Monograph 77:33-52.

Rodríguez, C., E. Leoni, F. Lezama, and A. Altesor. 2003. Temporal trends in species composition and plant traits in natural grasslands of Uruguay. Journal of Vegetation Science 14:433-440.

Rosengurtt, B. 1979. Tablas de comportamiento de las especies de plantas de campos naturales en el Uruguay. Universidad de la República, Facultad de Agronomía, Montevideo, Uruguay.

Ryser, P., and P. Urbas. 2000. Ecological significance of leaf lifespan among Central European grass species. Oikos 91:41-50.

SAS Institute. 2005. Statistycal Analysis System (SAS). Version 9.1. SAS Institute, Cary, North Carolina, USA.

Soriano, A. 1991. Río de la Plata grasslands. p. 367-407. In Coupland, R.T (ed.) Natural grasslands: Introduction and Western Hemisphere. Elsevier, Amsterdam, The Netherlands.

Sosinski, E., and V. Pillar. 2004. Response of plant functional types to grazing intensity in grasslands. Pesquisa Agropecuária Brasileira 39:1-9.

Vesk, P., M. Leishman, and M. Westoby. 2004. Simple traits do not predict grazing response in Australian dry shrublands and woodlands. Journal of Applied Ecology 41:22-31.

Vesk, P., and M. Westoby. 2001. Predicting plant species responses to grazing. Journal of Applied Ecology 38:897-909.

Weiher, E., A. Van der Werf, K. Thompson, M. Roderick, E. Garnier, and O. Eriksson. 1999. Challenging theophrastus: a common core list of plant traits for functional ecology. Journal of Vegetation Science 10:609-620.

Westoby, M. 1998. A leaf-height-seed (LHS) plant ecology strategy scheme. Plant and Soil 199:213-227.

Wilson, P.J., K. Thompson, and J.G. Hodgson. 1999. Specific leaf area and leaf dry matter content as alternative predictors of plant strategies. New Phytologist 143:155-62. 